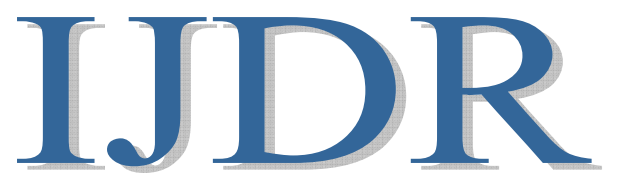

International Journal of Development Research

Vol. 10, Issue, 06, pp. 36802-36808, June, 2020

https://doi.org/10.37118/ijdr.19047.06.2020

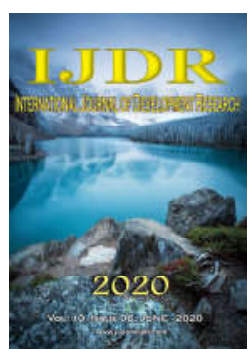

\title{
LOW COST HOME AUTOMOTATION WITH ESP32
}

\section{${ }^{1}$ Carlos Willames Paiva Amâncio, ${ }^{1}$ Bruno Pereira Gonçalves, ${ }^{1}$ Rilmar Pereira Gomes, ${ }^{1}$ Mayre Vane Serafim da Silva, ${ }^{1}$ Jean Mark Lobo de Oliveira and ${ }^{2, *}$ David Barbosa de Alencar}

\author{
${ }^{1}$ Academic department, University Center FAMETRO, Amazon-Brazil \\ 2Institute of Technology and Education Galileo of Amazon (ITEGAM), Brazil
}

\section{ARTICLE INFO}

Article History:

Received $22^{\text {nd }}$ March, 2020

Received in revised form

$06^{\text {th }}$ April, 2020

Accepted $04^{\text {th }}$ May, 2020

Published online $29^{\text {th }}$ June, 2020

Key words:

Home Automation, Esp32, Wi-Fi,

Lighting, Smartphone.

*Corresponding author:

David Barbosa de Alencar

\begin{abstract}
Affordable home automation using an ESP32 low power controller. Applying bibliographic research to understand the concepts required for the preparation of the work and adopting quantitative research through a questionnaire to a random audience. Also, a research documentation to support information in formal and informal bodies. It was exemplified through a case study using a visual model representing a popular residence with five rooms where it was possible to carry out the automation of the lighting system through mobile devices using the WIFI network and an app made in the app inventor, a user interface. As result, it was possible to notice the benefits that an automated residence can provide, such as comfort, practicality, safety and economy.
\end{abstract}

Copyright (C) 2020, Carlos Willames Paiva Amâncio et al. This is an open access article distributed under the Creative Commons Attribution License, which permits unrestricted use, distribution, and reproduction in any medium, provided the original work is properly cited.

Citation: Carlos Willames Paiva Amâncio, Bruno Pereira Gonçalves, Rilmar Pereira Gomes, Mayre Vane Serafim da Silva, Jean Mark Lobo de Oliveira and David Barbosa de Alencar, "Low cost home automotation with esp32”, International Journal of Development Research, 10, 06, 36802-36808.

\section{INTRODUCTION}

One of the great challenges in a home is the rational use of electric energy. With the enormous demand for technology today, it is almost impossible to abstain from a certain appliance and even more difficult to use it economically. According to a report by the National Energy Balance about information on how much and how energy was used in Brazil in 2018 , the final consumption of electricity in the country increased by $1.4 \%$ and one of the sectors that contributed to the increase in absolute values is the residential which expanded its consumption by $1.8 \mathrm{TWh}$ with a $1.3 \%$ growth (BEN, 2019). The waste of energy is one of the factors that increases consumption in all segments, between the years 2015 to 2017 there was a large expenditure of 52 billion reais in two years with the uncontrolled use of energy (Abesco, 2018). Today's society demands that implementation processes be created for the rational use of natural resources, and that it be low-cost, accessible and non-polluting. Automation is present in all stages of the electric energy process from generation, transmission and distribution in residential homes and its transformation follows the fast population growth and modernization of cities. With the mission of promoting the use of resources in an economical and sustainable way, several works seek in automation an alternative to develop systems of control and monitoring of environments, with the intention not only of optimizing energy consumption but also the convenience and the mobility of people present in these environments. Home automation is currently one of the alternatives to minimize the consumption of electricity in a home while also providing comfort, security, communication, mobility and even adding value to the property in the real estate market. Projects of home automation systems such as lighting control, monitoring cameras, gate, gardens, swimming pools and others can reduce up to $40 \%$ of electricity consumption (FECOMECIO SP, 2015). Incentives for projects with the principle of sustainability, such as reducing energy consumption, are found in several development companies and awards available for the best projects. 


\section{BIBLIOGRAPHIC REVIEW}

Home automation: Home automation comes from two words, the first in Latin domus, which refers to the home and the second to robotics, refers to the automation of something by robots. The two words define and simplify the automation process of the home environment. With the advancement of electronics and telecommunications over the years, several devices became accessible to the consumer, making it almost impossible to imagine an automated environment without a cell phone or tablets. The mechanism of allowing something to be controlled autonomously and controlling something centrally or remotely are the key and broadest terms for home automation (JUNIOR, FARINELLI, 2019).

Basic elements: To carry out a home automation project, it is necessary to know the basic elements that make up a home automation system; Controllers: Embedded devices capable of controlling actuators and sensors. Sensors:

They are devices that detect stimuli, measure and monitor physical quantities. Actuators: Electromechanical devices that receive commands from the controllers through the busbars. Busbars: They are physical means responsible for the transport of information. Interface: It is the means by which users interact with the system. (ACCARDI, DODONOV, 2012).

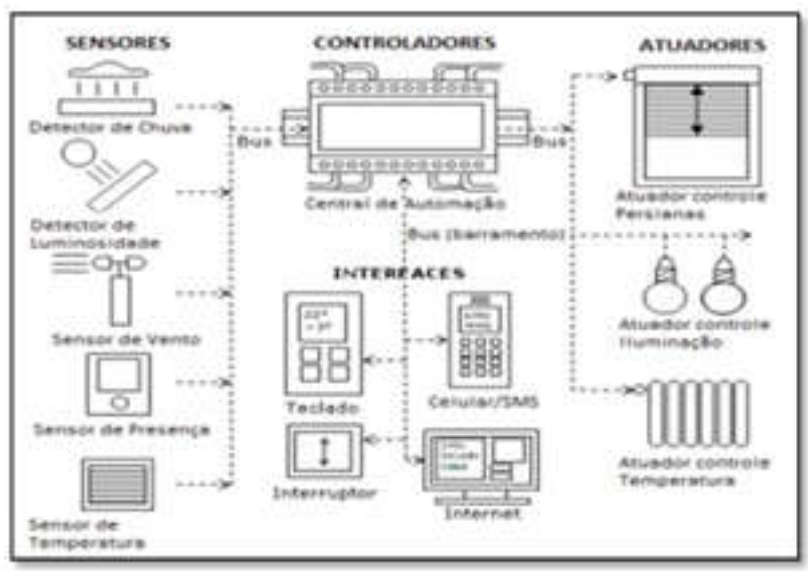

Source: (CASADOMO, 2010)

Fig. 1. Basic automation element

Home Automation Architectures: In Home Automation the definition of architecture is given by the arrangement of the basic elements and the way they communicate, resulting in two types of architecture: centralized and decentralized.

Centralized Architecture: In the centralized architecture as shown in figure 2, all devices respond to a centralizing element responsible for receiving, sending and handling information from sensors, actuators and interface.

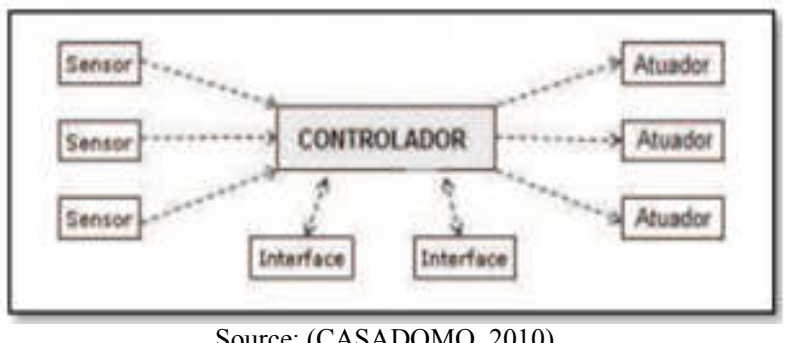

Source: (CASADOMO, 2010).

Fig. 2: Centralized architecture
Decentralized Architecture: In decentralized architecture, it is possible to find two or more controlling elements that share element management via busbar.

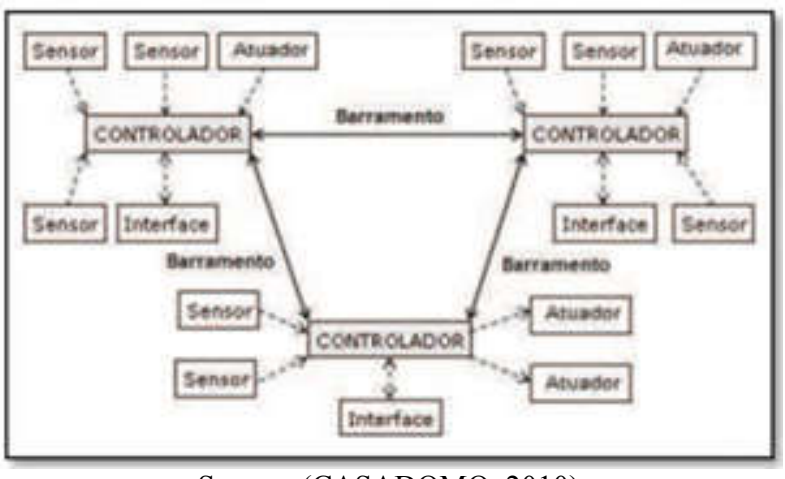

Source: (CASADOMO, 2010)

Fig. 3: Decentralized architecture

Microcontrollers: Microcontrollers are small embedded devices very similar to a microcomputer with processor, rom and ram memory, input and output peripherals, analog and digital converters. These devices are normally programmed to perform a specific function efficiently and stored in read-only memory and some reprogramming liabilities are also limited by ram. It has smaller printed circuit boards, smaller memory addressing and a very affordable market price. Currently, there are several models of microcontrollers on the market such as Arduino, ESP32, and Raspberry Pi all with their memory and different processing (TOKHEIM, 2013).

ESP-32 Controller: In 2015, the company named Espressif from China origin, launched the microcontroller 8266 of RISC 32-bit architecture, built-in WIFI module, smaller than found on the market and with a very affordable price. Something at the time innovative and with great technological potential, mainly for prototyping in industrial and residential automation projects. In 2016 it made improvements and created new features and launched the ESP32 with the Bluetooth module, twice the processing speed being dual core, frequency of 160 $\mathrm{MHz}$, considerably increased SRAM memory and number of output and input pins (SOUZA 2018).

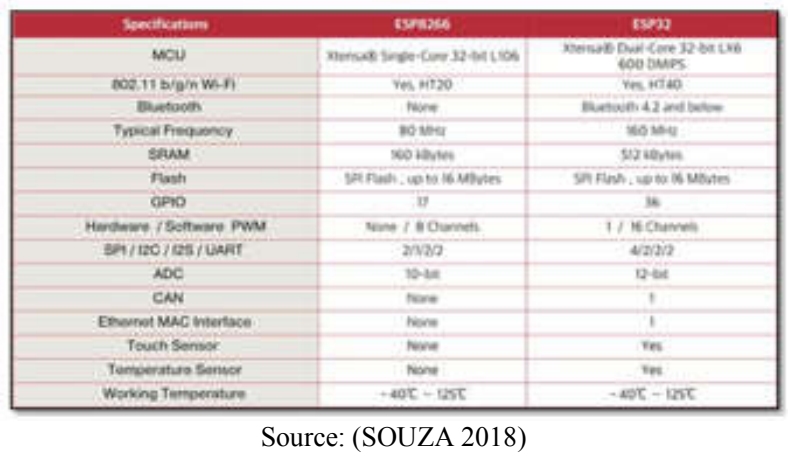

Fig. 4: Features between ESP 8266 and ESP32

With so many resources available in the esp32, it is necessary to know the basics of the board. First, the device has two buttons, the first is called BOOT, which allows recording on the device, and the second one is the EN button, performing the reset on the module starting the system again. The board is powered by the USB connector with a voltage of $5 \mathrm{~V}$, outputs regulated for the Vin pin $(5 \mathrm{~V})$ and $3.3 \mathrm{~V}, 2$ pins for GND. 
The pinning system has 18 channels of analog to digital converter (ADC), 2 digital-to-analog converters (DAC), 10 GPIOs with capacitive detection and others as shown in figure 6. The block diagram represents the modules existing in the embedded device with their respective colors in our prototype we will use the WIFI module.

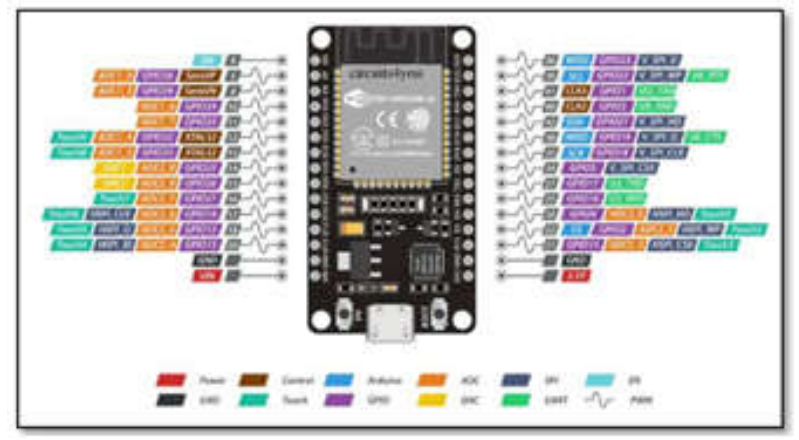

Source: Circuits4you

Fig. 5: Pinning System of ESP32

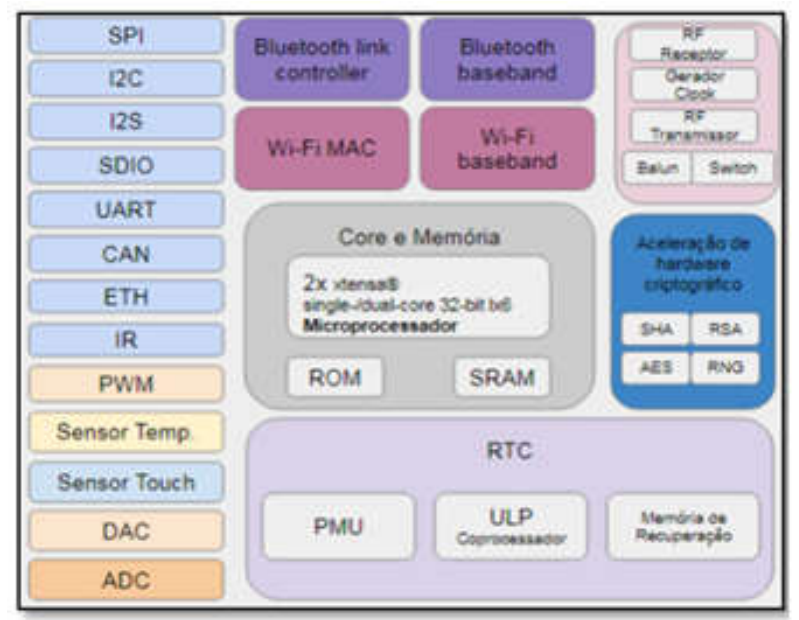

Source: Circuits4you

Fig. 6: Diagram of the components of the ESP32

Relay: Relays are electromagnetic switches formed by a coil; a set of contacts capable of controlling large high voltage circuits through low voltage circuits. This control occurs in isolation from the controlled circuit, resulting in totally separate circuits, generating security for the system. The relay has two states - normally open and normally closed (Braga, 2019).

Normally closed: Relay with normally closed contacts or NC (normally close) is described by a pair of contacts that remain united when the relay coil is not energized. When the coil energizes, the pair of contacts separate, resulting in the interruption of the current in the controller circuit as shown in figure 7.

Normally open: Relay with normally open or NO contacts (normally open) is characterized by a pair of contacts that remain separate until the moment the coil receives a voltage and current resulting in the union of the contacts and closing the circuit. NO contacts are used to connect a circuit from a command or control signal as shown in figure 8 .

Arduino Ide: The Arduino IDE is a multiplatform development environment written in java with the objective of creating code with syntax highlighting features, corresponding

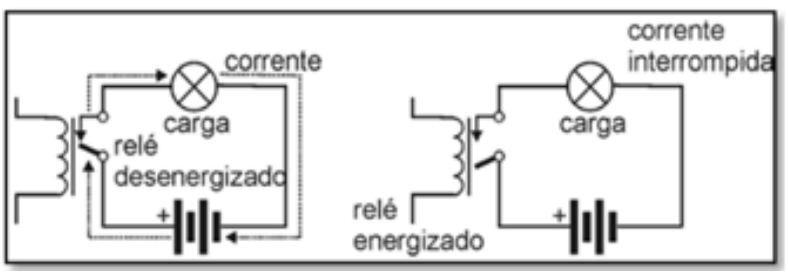

Source: BRAGA (2017).

Fig. 7: Relay with contact N.C.

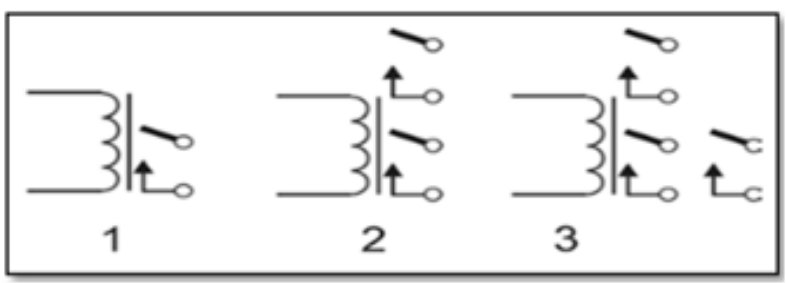

Source: BRAGA (2017).

Figure 8-Relay with contact N.A.

parentheses and automatic indentation, being able to compile and load programs to the controller board. Also, it has a library called "Wiring", accepting programming in $\mathrm{C}$ and $\mathrm{C}++$ in a structured form.

App Inventor: The App Inventor is an online development environment developed by Google and MIT - Massachusetts Institute of Technology where all programming is developed using blocks and allows the creation of applications for mobile devices that use the Android operating system. The highlight of this tool is that the development does not require high knowledge in programming, besides being simple and didactic. Applications can be developed using a simple web interface, which works through the fitting of available logical blocks. Also, it allows to emulate the application, import and export projects to mobile device.

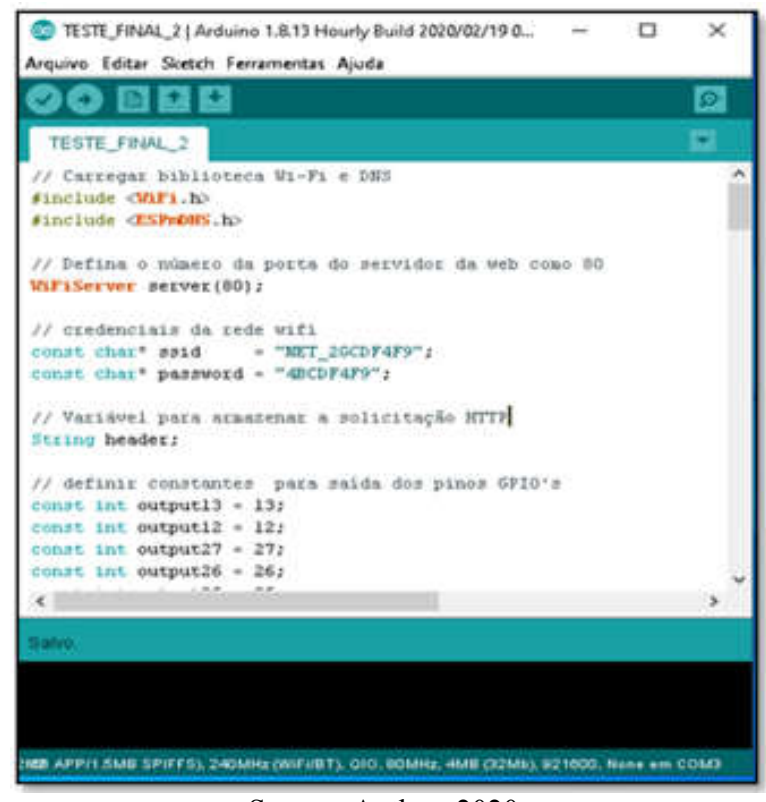

Source: Author, 2020

Fig. 9: Arduino IDE

\section{MATERIALS AND METHODS}

For this work, bibliographic researches were carried out to be the base of the knowledge on the subject. A case study was carried out by building a visual model to represent. 


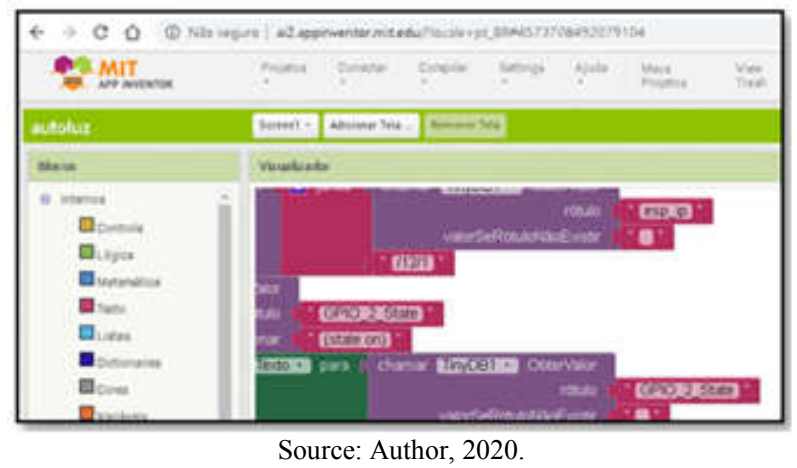

Fig. 10: App Interface

Quantitative research was also applied through a questionnaire on an online platform with 10 objective questions for the subject addressed with random people. A case study was carried out and a visual model was built that simulates the home environment with automation. The SP32 was used as a controller for activating the actuators and sensors; RELAY, was used for triggering loads; PROTOBORD, it was used to connect the ESP32 and relays for triggering the loads; USB CABLE, it was used for recording the Sketch's on ESP32 with the notebook; LED LAMP, it was used in the rooms of the house; NOTEBOOK, it was used to install the IDE ARDUINO, ESP32 drivers, libraries; ROUTED, it was used to establish a wireless local network; VISUAL MODEL, it was used to simulate the system for lighting the rooms of the residence; IDE ARDUINO, it was used for programming and recording Sketchs; SOURCE OF $5 \mathrm{~V}$, A source of $5 \mathrm{v} / 1 \mathrm{~A}$ it was used to power the controller.

\section{RESULTS AND DISCUSSION}

Physical environment: The development will be based on a popular house model usually built by the program called "minha casa minha vida" (my house my life) with two bedrooms, living room, kitchen and bathroom totaling $41.16 \mathrm{~m}^{2}$; however, on a smaller scale that will be represented by a visual model according to the floor plan in figure 11 . In the house each room has a lamp totaling 5 LED lamps $9 \mathrm{~W}$ and 6 plugs of $110 \mathrm{v}$ and 2 plugs of 220 volts according to the electrical project below.

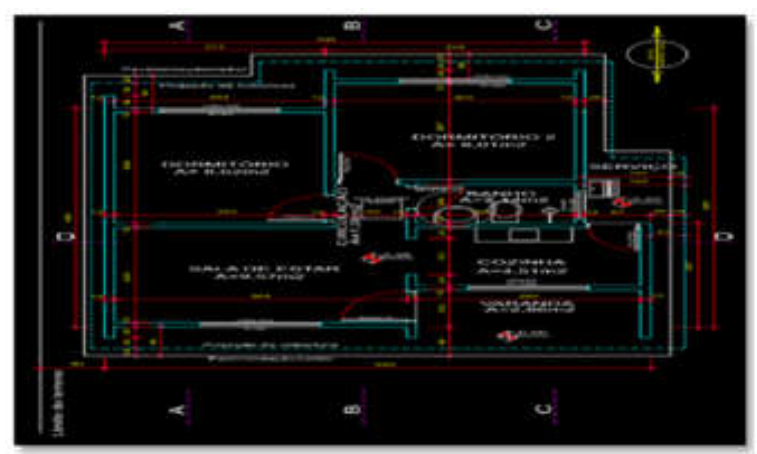

Source: Caixa Habitação (2016)

Fig. 11: Low Plant A=41,16 M2 ESC.:1:50

Visual model construction: For the construction of our model, a plywood sheet with dimensions of $2.20 \mathrm{mx} 1.6 \mathrm{mx} 10$ $\mathrm{mm}$ was used, where the work of cuts and fixing of each room was carried out, a $5 \mathrm{~cm}$ diameter hole was also made to insert the adapter for each lamp. In addition, to create the electrical part, 16 meters of $2.5 \mathrm{~mm}$ wire were used.

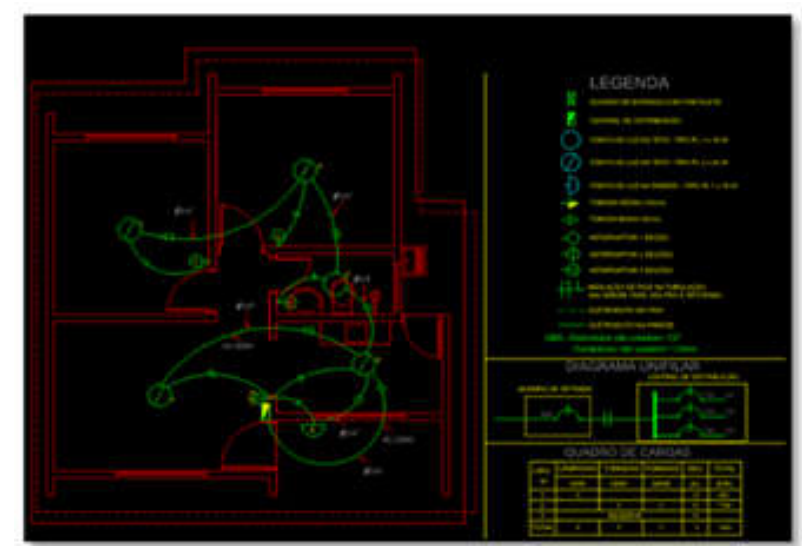

Source: Caixa Habitação (2016).

Fig. 12: Electrical Project

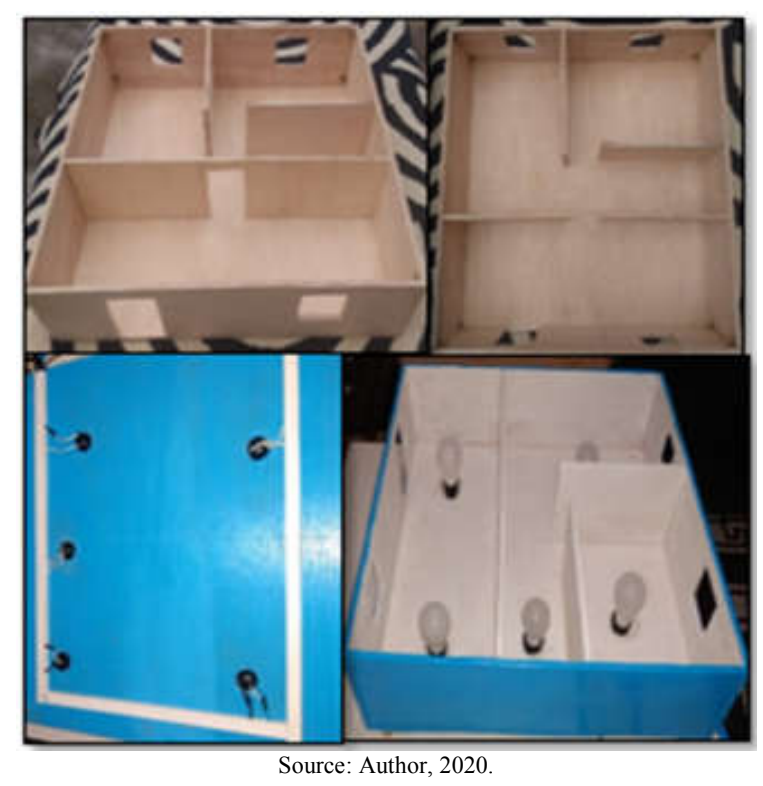

Fig. 13: Visual Model Construction

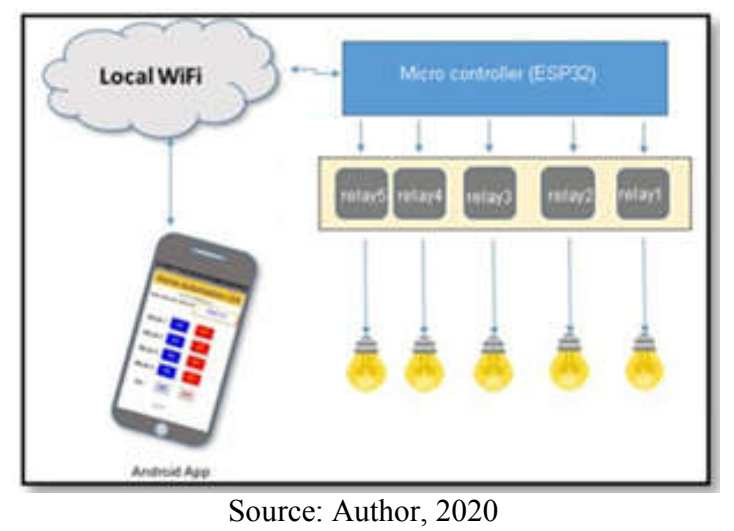

Fig. 14: System illustration

Hardware implementation: The implementation presented has the main objective of automating the lighting system of a residence via mobile devices such as tablets and smartphones, and can also be applied to other sectors of the house such as doors, curtains and plugs. Figure 13 illustrates well the scenario that will be carried out where each relay will be related to a room in the house. In this phase, we started the assembly of the electrical components in the visual model. The first room to receive the connection with relay 1 will be the living room, then the kitchen relay 2, bedroom 1 relay 3 , bedroom 2 relays 4 and the bathroom relay 5 . 
With the part electrical and finished connections, we can direct the output of each pin of the relay to ESP32 as in the basic diagram figure 14 the positive pin of relay 1 connects to the VIM pin of the controller, the GND of the relay to the GND of it and finally the signal pin the D13 port. In the same order we can connect the other rooms to the following ports D12, D27, D26 and D25. To supply the controller, a 5V source was used.

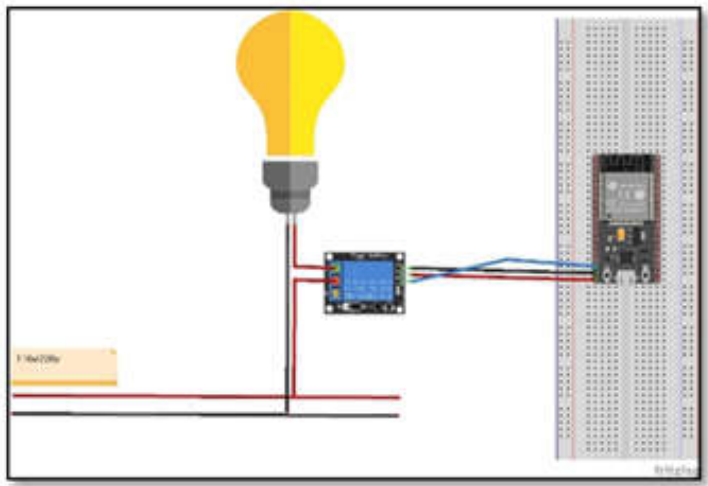

Source: Author, 2020.

Fig. 15: Basic example

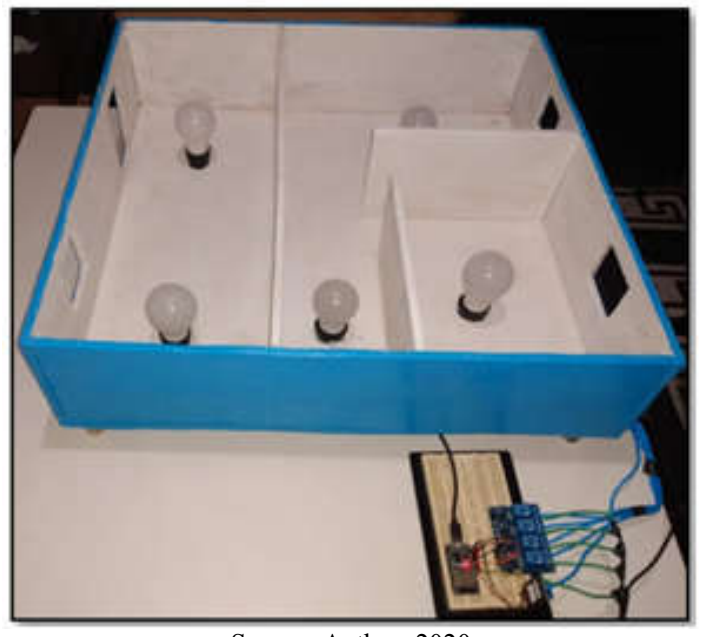

Source: Author, 2020

Fig. 16: Visual model concluded

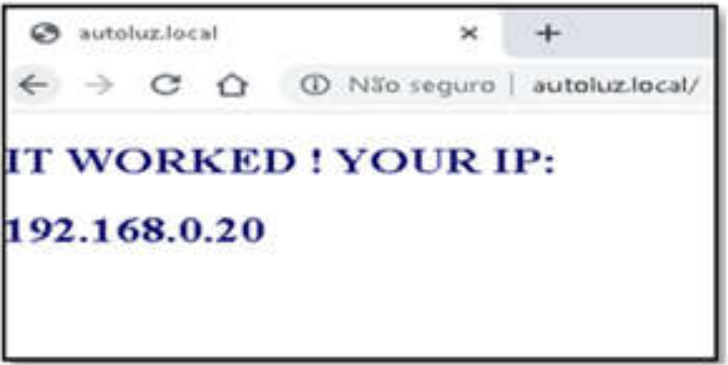

Source: Author, 2020.

Fig. 17: Web server access

Software implementation: To implement the code, the Arduino IDE was properly configured to operate in conjunction with the ESP32. The controller will have the role of web server where it will send and receive requests from mobile devices connected to the local network. To connect to the network, it was programmed to establish communication with the router using a password and ssid, when connected the blue LED of the controller will be flashing indicating that the controller is already available.

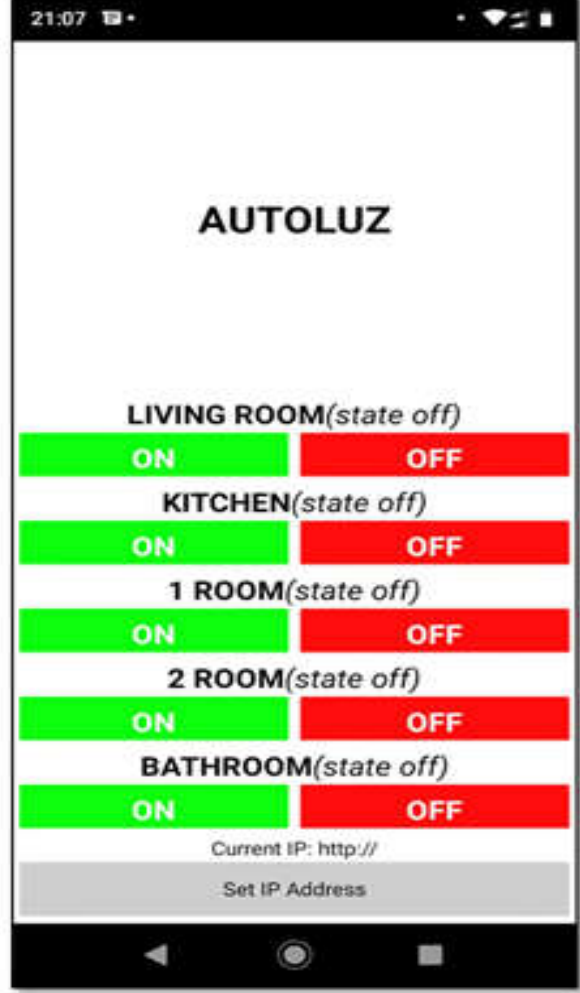

Source: Author, 2020

Fig. 18: Android Ap

Table 1-Results

\begin{tabular}{ll}
\hline RESULTS ACHIEVED & \\
\hline App Developed & Ok \\
ESP32 program with Arduino IDE & Ok \\
ESP32 recognize router Wi-Fi signal & Ok \\
Establish communication between App and ESP32 & Ok \\
ESP32 start the relay with the App & Ok
\end{tabular}

Source: Author, 2020.

\section{Do you know residential automation?}

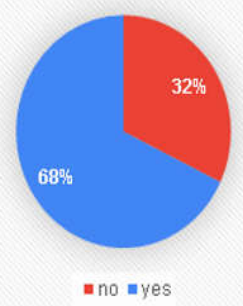

Source: Author, 2020

Fig. 19: Question 1 Do you know residential automation?

\section{Do you have interest in residential automation?}

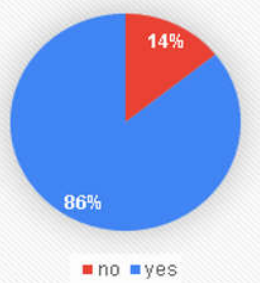

Source: Author, 2020.

Fig. 20: Question 2 Do you have interest in residential automation? 


\section{Do you know the value of a home automation project?}

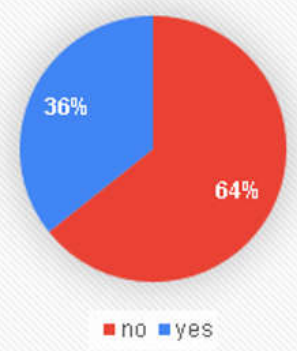

Source: Author, 2020

Figure 21-Question 4 Do you know the value of a home automation project?

\section{How much could you pay for a home automation project?}

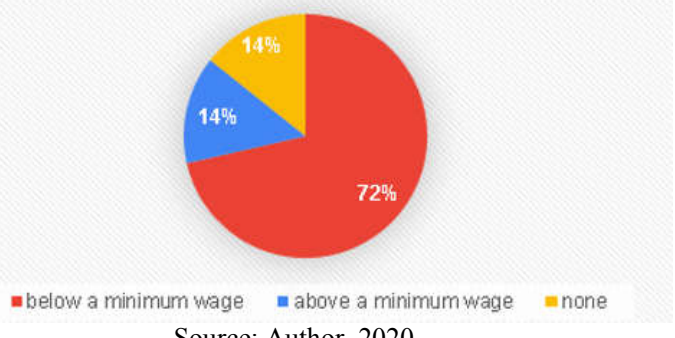

Source: Author, 2020

Figure 22-Question 5 How much could you pay for a home automation project?

To perform the test, just type in a browser the URL address http: //utoluz.local that will display the message it worked and the server IP. For user interface, an application was developed on the android platform using block programming available in App Inventor. For the development of the app, several studies and tests were necessary to reach an acceptable level of communication with the controller. The application has two buttons for each room in the house, a label that identifies the status of the button and a button described as Set Ip address that when pressed, it enables a field to enter the IP of the web server and a save button. With the stable communication of the app, router and controller can trigger loads using the wireless network providing comfort, mobility and achieving the results expected in this prototype for automation of the home lighting system. According to the table below, the results were achieved.

Survey results: After applying the survey, we obtained a total of 28 responses and were able to gather relevant information for the development of the prototype for our automation. Some questions were selected to demonstrate the result. Analysis of the answer on knowledge and interest about home automation. Based on questions 1 and 2, we found that $60.7 \%$ of people know what is home automation. Also, 78.6\% showed real interest in the subject. Observing in the results, the existence of a certain demand and seeks to automate routines in a residence. Regarding the values of a home automation project, an analysis was made of questions 4 and 5 . Where $64.3 \%$ do not know the values for preparing an automation project and $64.3 \%$ are willing to invest less than the minimum wage. With the income statement, it is possible to notice the lack of knowledge of the values applied in the home automation market and the willingness to invest in low-cost and accessible technologies and solutions for the population.

\section{Conclusion}

The demonstrated prototype aimed to perform low-cost home automation using ESP32 as a controller for loading loads. The lighting system was chosen to be automated in the residence. To represent the residence, a visual model was elaborated with the lighting system where the lamps are activated through mobile devices. The chosen controller proved to be efficient and low energy consumption in addition to the low value when compared to those existing on the market. In addition to the automation of the lighting system, the possibility of applying the concept to control access to doors, curtains and temperature using the wireless or Bluetooth network was also noted.

\section{Acknowledgments}

Firstly, to God for the gift of life without Him it would not be possible to develop this project. Also, to the Professor Bruno Pereira Gonçalves, the coordination and the faculty members of FAMETRO University. Moreover, for the support of my wife Fernanda and my children Kalebe, Rafael and Davi.

\section{REFERENCES}

Almeida, R. M. A., Moraes, C. H. V.Programação de sistemas embarcados - Desenvolvendo software para microcontroladores em linguagem C. Elsevier, 2016.

Andrade, F. S. D., Oliveira, A. S. D. Sistemas Embarcados Hardware e Firmware na Prática. Érica, 2010.

Abesco. O que é Eficiência Energética ? (EE). São Paulo, 2018. Disponível em: $<$ http://www.abesco.com.br/pt/o-quee-eficiencia-energetica-ee/>. Acesso em: 7 de fevereiro de 2020.

Accardi, Adonis; Dodonov, Eugeni. Automação Residencial: Elementos Básicos, Arquiteturas, Setores, Aplicações e Protocolos. Revista -T.I.S., São Carlos, v. 1, n. 2, p. 156166, nov. 2012

Bolzani, Caio A.M. Residências Inteligentes: um curso de Domótica. São Paulo: Livraria da Física, 2004.

Braga, Newton. Eletrônica para Eletricistas, NCB,2019.

Braga, Newton. Relés-Circuitos e aplicações, São Paulo, NCB, 2017.

Casadomo. Domótica - Introducción. Agosto 2010. Disponível em: $<$ http://www.casadomo.com/>.

Caixa Habitação. Projeto completo de casa popular. junho 2016. Disponível em:< https://caixahabitacao.com/plantasde-casas-pequenas-gratis-projeto-completo-de-casapopular- $41 \mathrm{~m} \% \mathrm{c} 2 \% \mathrm{~b} 2 />$. Acesso em: 14 de fevereiro de 2020.

Curto Circuito. Tutorial: Conhecendo o Esp32.Disponível em: $<$ https://www.curtocircuito.com.br/blog/conhecendoesp32/>. Acesso em: 14 de fevereiro de 2020.

Ben - Balanço Energético Nacional. Balanço Energético Nacional 2019 (ano base:2018). Empresa de Pesquisa Energética, Rio de Janeiro, 2019.

Fecomercio-SP. Tecnologia aliada na redução do consumo de energia. São Paulo, 2015. Disponível em: $<\mathrm{http}$ ://www.abesco.com.br/pt/o-que-e-eficiênciaenergética-ee/>. Acesso em: 14 de fevereiro de 2020.

Junior, S.L.S., Farinelli, F.A. Domótica: Automação residencial e casas inteligentes com Arduino e ESP8266. [S.1.: s.n.], 2019.

Kolban, Neil. Kolban's Book on ESP32.Texas, USA. 2015 
Mcroberts, Michael Arduino básico; São Paulo: Novatec Editora, 2011.

Mamede Filho, João. Instalações Elétricas Residenciais. 8. ${ }^{\mathrm{a}}$ ed. Rio de Janeiro: LTC. 2010.
Souza, Vitor Amadeu. Programando o ESP32 no Arduino. CERNE, 2018.

Tokheim, Roger. Fundamentos de Eletrônica Digital-Vol.2: Sistemas Sequenciais. Série Tekne. 7. ed. Brasil: Mcgraw Hill, Bookman, 2013. 